\title{
Expletive negation in exclamatives - Evidence from Hungarian
}

\author{
TAMÁS HALM ${ }^{1,2 *}$ (1) and ANNA HUSZÁR R ${ }^{1,2}$ \\ ${ }^{1}$ Pázmány Péter Catholic University, Budapest, Hungary \\ ${ }^{2}$ Hungarian Research Centre for Linguistics, Budapest, Hungary
}

Received: November 23, 2020 • Revised manuscript received: October 13, 2021 - Accepted: October 14, 2021

(c) 2021 The Author(s)

\begin{abstract}
This paper examines expletive negation in root clauses (surprise negation sentences and wh-exclamatives) in Hungarian. We argue that Hungarian has three distinct negation positions, each corresponding to a truth-reversal operation on a different level. When the negator nem 'no' is merged in the CP layer (in the head position of the Speaker Deixis Phrase), this yields surprise negation sentences, corresponding to negation at the level of presuppositions (expletive negation). The negator being merged as the head of NegP within the extended TP yields standard negation (at the propositional level). In wh-exclamatives, the negator is head-adjoined to $\mathrm{T}^{0}$, which results in negation at the level of implicatures (expletive negation). In addition to pointing out this mapping between syntactic position and semantic-pragmatic interpretation, we also argue that the data from Hungarian present a strong case against a raising analysis of expletive negation.
\end{abstract}

\section{KEYWORDS}

expletive negation, exclamatives, surprise negation, Hungarian

\section{INTRODUCTION}

Expletive negation (broadly speaking, instances where a sole negator seems not to modify the truth-value of the proposition) has been at the forefront of research interest recently. Espinal (2000) analyzed expletive negation and negative concord in a uniform feature-checking

*Corresponding author. E-mail: halm.tamas@gmail.com 
framework, postulating that in both cases, the negator occupies the same syntactic position $\left(\mathrm{Neg}^{0}\right.$ of a NegP above TP), with the crucial difference being that in the case of expletive negation, the negator is licensed by a higher non-veridical operator. In his in-depth analysis of Italian, Greco $(2018,2019 b)$ introduces a finer distinction between strong expletive negation and weak expletive negation (based on licensing facts related to strong NPIs and N-words). Greco (2019a) discusesses expletive negation in so-called surprise negation sentences (or Snegs) in Italian in a phase-theoretic framework, proposing that whether the same negative marker receives an expletive interpretation depends on whether it is merged in the $\mathrm{v}^{*} \mathrm{P}$ phase or later in the CP phase. Delfitto, Melloni \& Vender (2019), developing an idea introduced by Greco (2018, 2019ab), argue that expletive negation is a truth-value reversal operation, just like standard negation, however, its domain of operation is different. While standard negation operates on the asserted meaning of the utterance, expletive negation operates on a presupposition or an implicature of the utterance.

While much of the discussion of expletive negation has so far been based on Romance languages (such as Catalan, Spanish, Italian or French), in this paper, we discuss hitherto unexplored data concerning expletive negation in Hungarian focusing on exclamatives, the only environment where expletive negation is attested in a root clause. We will show that (i) the expletive negator is in a structurally different position to standard negation and (ii) that the expletive negator itself has different structural positions depending on whether it is in a whexclamative (1c) or a surprise negation sentence (1d):
a. János el olvasott sok könyvet.
John PRT $^{1}$ read.PAST.3SG many book.ACC
'John read many books.'
b. János nem olvasott el sok könyvet. (standard negation) John not read.PAST.3SG PRT many book.ACC 'John did not read many books.'
c. (Hogy) János miket el (nem) olvasott. (expl. neg., wh-exclamative) that John what.PL.ACC PRT not read.PAST.3SG
'What (surprising, unexpected) things John has read!'
d. (Hát) János nem el olvasott egy könyvet!? (expl. neg., surprise neg.) well John not PRT read.PAST.3SG a book.ACC
'John has read a book! (surprisingly)'

We will claim that these data favour a broadly Greco (2019a)-style analysis (where different readings of the negator are associated with different structural positions) as opposed to an Espinal (2000)-style analysis (where standard and expletive negators are in the same position). Also, we will argue that the data from Hungarian provide a nice fit with Delfitto, Meloni \& Vender's (2019) semantic-pragmatic proposal, inasmuch as the domain of operation (implication, assertion, presupposition) is clearly mapped to the syntactic position of the negator.

Our concrete proposal is that Hungarian has three distinct negation positions, each corresponding to a truth-reversal operation on a different level:

\footnotetext{
${ }^{1}$ Verbal particles express the result state or location of the theme argument.
} 
(2)

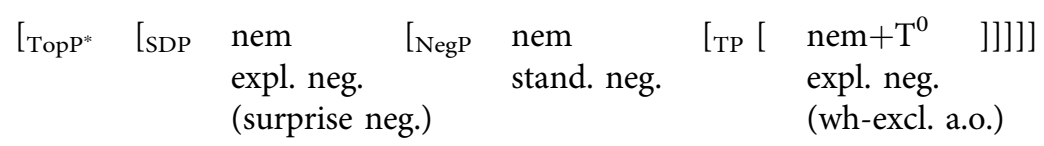

There is a clear mapping between syntax and semantics: a negator merged in High Negation position (Speaker Deixis Phrase, SDP) encodes negation at the level of presuppositions: this yields Expletive Negation in surprise negation sentences. A negator merged in the Middle Negation position (NegP) yields negation at the propositional level: this is Standard Negation. A negator merged in the Low Negation position (head-adjunction to $\mathrm{T}^{0}$ ) yields negation at the level of implicatures (Expletive Negation in wh-exclamatives, until-clauses etc.). ${ }^{2}$

Furthermore, we will argue that in surprise negation sentences, an expletive negator in SDP can freely cooccur with a standard negator in NegP: this precludes any analysis of expletive negation in surprise negation sentences as a case of raising, and it also means that raising cannot be a general mechanism of expletive negation (cf. Abels 2005 on Russian).

Also, we will provide evidence that in surprise negation sentences in Hungarian, focusing is freely available: this means that Greco's (2019a) analysis of surprise negation in Italian will only partially carry over to Hungarian: while the negator is merged TP-externally in what might be termed the extended topic field in both languages, the VP is not obligatorily focused in Hungarian (as opposed to Italian in Greco's (2019a) analysis).

In general, we will find that the observation of Delfitto, Melloni \& Vender (2019) that expletive negation in surprise negation sentences differs from all other types of expletive negation in terms of semantic/pragmatic effect (negation on the presuppositional vs. the implicational level) is in fact clearly reflected in syntactic position: while the expletive negator in surprise negation sentences is merged high in the functional left periphery (SDP in the broader topic field), the expletive negator in all other cases is TP-internal, being head-adjoined to $\mathrm{T}^{0}$.

The paper is structured as follows. In Section 2, we discuss the theoretical background and previous literature. Section 3 is dedicated to surprise negation sentences in Hungarian. Expletive negation in wh-exclamatives is discussed in Section 4. In Section 5, we spell out the theoretical implications of our findings. Further research directions are pointed out in Section 6. Section 7 concludes the paper.

\section{BACKGROUND AND PREVIOUS LITERATURE}

The terms expletive or pleonastic negation have traditionally been used in the literature for instances of negation where the negator does not seem to have any truth-conditional contribution to interpretation (cf. Delfitto, Melloni \& Vender 2019 for a recent overview). Unlike standard sentential negation, expletive negation does not reverse the polarity of the clause in which it occurs, and differs from standard negation in its polarity item-licensing properties as well (rejecting strong NPIs, while allowing PPIs in its scope). Expletive negation is arguably a feature of negative concord languages, with the exception of expletive negation in exclamatives, which is attested in non-NC languages as well, like Dutch or English (Zeijlstra 2004), and has a tendency to be optional and occur with a non-indicative mood such as subjunctive. The

\footnotetext{
${ }^{2}$ As we will argue below, all three positions are base positions for the negator.
} 
occurrence of EN is limited to a well-defined set of utterances, including temporal, comparative or exclamative clauses, as well as complex sentences containing predicates expressing fear, hindrance, unlikeliness or contrast. There is, however, cross-linguistic (as well as diachronic) variation as to which of these environments license EN in a given language (at a given time). This section gives a brief overview of the existing approaches to expletive negation, which have been proposed over the course of the past thirty years.

The pleonastic (or paratactic) approach of Jespersen (1917), Espinal (1997, 2000), van der Wouden (1994, 1997), Zeijlstra (2004) and Brown \& Franks (1995) treats expletive negation as an instance of negation that is truth-conditionally irrelevant, making no negative contribution to sentential meaning whatsoever. Several, predominantly syntactic accounts sharing this approach (van der Wouden 1994, 1997; Espinal 1997, 2000; Zeijlstra 2004) argue that expletive negative elements are licensed by an operator from a higher clause, analysing expletive negation as an instance of long-distance negative concord. Though the mechanisms are similar, the property that EN-licensing elements share slightly differs in each account.

Drawing on the works of van der Wouden $(1994,1997)$, Espinal $(1997,2000)$ argued that negative elements in EN constructions are interpreted as negative polarity items. She analysed expletive negation and negative concord in a minimalist uniform feature-checking framework, postulating that in both cases, the negator occupies the same syntactic position $\left(\mathrm{Neg}^{0}\right.$ of a $\mathrm{NegP}$ above TP), with the crucial difference that in the case of expletive negation, the negator is licensed by a higher nonveridical operator, while NC relations involve an averidical operator. Besides subordinated clauses, Espinal (2000) extended her account to EN in matrix clauses as well (namely wh-exclamatives), by postulating a silent DegP (degree) projection above CP (Espinal 2000), making this projection the source of nonveridicality in the clause.

Zeijlstra (2004) also treated EN as an instance of long-distance NC, an operation possible in clauses that are in the subjunctive mood only. In this account expletive negative elements are licensed by semi-negative verbs (fear, doubt) or prepositions (without) in the matrix clause, which can (arguably) be lexically decomposed into a negative and non-negative part, thus carrying an [iNEG] feature. Since EN is deemed a NC phenomenon by Zeijlstra (2004), exclamatives licensing EN (attested in non-NC languages as well, like Dutch) are ignored here.

Finally, the accounts of Brown \& Franks (1995 and later works) do not attribute truthfunctional contribution to the expletive negator either, analysing the expletive negator as the head of a NegP lacking a negation operator. What this analysis has in common with the ones above is that according to Brown \& Franks (1995), the completely vacuous operator found in an expletive NegP also needs to be licensed under antecedent-government by a c-commanding real $\mathrm{OP}$. The exact nature of real OP, however is left somewhat unclear.

Another influential approach in the literature of expletive negation is one which treats EN as a spelt-out form of evaluative modality (Yoon 2011, a.o.). This predominantly semantic account deals with expletive negation in rhetorical comparatives, arguing that similarly to the subjunctive mood and NPIs, the role of EN is to rhetoricise comparatives, and "to convey the speakers' negative attitude towards the content of the proposition" (Yoon 2011, 235), acting as an evaluative mood marker instead of a logical negator.

Zovko Dinković \& Ilc (2017) combined the semantics of the evaluative approach with the syntactic analysis of Abels (2005), arguing that EN differs from standard negation in its syntactic scope: while standard negation (positioned in TP) has sentential scope, EN moves out of TP into $\mathrm{CP}$, where it scopes over the evaluative force, assuming local scope 
only. In this approach the properties of $\mathrm{EN}$ follow from its syntactic derivation, considering EN “akin to other means of expressing modality in natural languages" (Zovko Dinković \& Ilc 2017).

In his detailed analysis of EN in Italian, Greco $(2018,2019 b)$ introduces a finer distinction between strong and weak expletive negation (based on licensing facts related to strong NPIs and Negative Concord Items). Greco (2019a) discusses expletive negation in so-called Surprise negation sentences (or Snegs) in Italian in a phase-theoretic framework, proposing that whether the same negative marker receives an expletive interpretation depends on whether it is merged in the $\mathrm{V}^{*} \mathrm{P}$ phase or later in the CP phase - an idea similar to but not identical with that of Abels (2005) and Zovko Dinković \& Ilc (2017), who based their analysis on the operations of movement and reconstruction, not external merge.

Finally, Delfitto, Melloni \& Vender (2019), developing an idea introduced by Greco (2018, 2019ab), argue that expletive negation is a truth-value reversal operation, just like standard negation, however, its domain of operation is different. While standard negation operates on the asserted meaning of the utterance, expletive negation operates on a presupposition or an implicature of the utterance. This semantico-pragmatic analysis also attempts to give a unified account of expletive negation and metalinguistic negation, considering the former a special case of the latter (Delfitto, Melloni \& Vender 2019).

Although expletive negation is attested in Hungarian as well, so far it has received sporadic scholarly attention only. The first to mention it was Simonyi $(1883,1902)$ in an exhaustive descriptive account of Hungarian complementizers and Hungarian word order. The majority of the discussion in Simonyi's works is about EN in until-clauses, but other structures with non-standard negation are identified as well: comparatives, question-like exclamatives, whexclamatives, and complex sentences containing verbs "of negative import" (in the sense of Jespersen (1917)). The works of Kálmán $(2001,2016)$ also contain a handful observations regarding non-standard negation in Hungarian (with a focus on wh-exclamatives and untilclauses), but offer no analysis either. A more recent account of EN in Hungarian is that of Gugán (2018, 2020), whose corpus studies focus on Middle Hungarian complex sentences containing negative evaluatives, quotatives or the complementizer until, pointing out the differences in the use of non-standard negation in these environments with regard to different factors, such as mood or polarity. As the study shows, negation may only be characterized as "truly expletive" in until-clauses in Middle Hungarian, and sentences with negative evaluatives contain what can be termed evaluative negation (in the sense of Yoon 2011) in the corpus, while negative quotatives contain standard clausal negation. Lastly, a different view is presented in MacDonald \& Ürögdi (2011) and Ürögdi (2013), who follow Abels (2005) in arguing that the non-standard interpretation of negation in Hungarian until-clauses is not the result of its expletive nature but its syntactic derivation: just like standard sentential negation it originates in NegP, but then it is covertly raised out of its TP-internal position, yielding the nonnegative reading.

\section{SURPRISE NEGATION SENTENCES}

Surprise negation sentences (henceforth: Snegs) are utterances which blend the pragmatic and prosodic properties of questions and exclamations, conveying a strong sense of surprise or 
disbelief. Apart from wh-exclamatives, they are the only root clauses which admit expletive negation in Hungarian. The following subsection will give a general overview of the main characteristics of this sentence type, drawing heavily on the detailed syntactic, prosodic and semantic account of Italian Snegs given by Greco (2019a); subsections 3.2-3.3 discuss negation in Snegs from a syntactic point of view, while subsections $4-5$ outline our syntactic and semantic analysis of expletive negation in Hungarian Snegs.

\subsection{Surprise negation sentences - a general overview}

As previously mentioned, Snegs are crossovers between an interrogative and an exclamative, similar to both but not identical to either. Their intonation is closest to the pattern characterized by Varga (2002) as a "descent-fall", an intonation pattern used "to express the speaker's disbelief or surprise over a piece of information (or experience) which (s)he already knows but finds unexpected" (Varga 2002, 40). This prosody, according to Varga (2002), is characteristic of certain types of interrogatives, the meaning of which is "neither genuinely questioning nor clearly exclaiming", but somehow both. Written language reflects this uncertainty, as Snegs are often marked with either a single question mark or an exclamation point, the combination of these two (?!), or even several of them (?!?, !?!, ...):

(Hát) János nem el olvasta
well John not PRT read.PAST.3sG the book.ACC
'John read the book! (surprisingly)'

The property that sets Hungarian (and Italian) Snegs apart from both exclamatives and interrogatives is that they only exist as root clauses, i.e. they cannot be embedded (Greco 2019a). (4b) and (4c) below contain a polar interrogative and a wh-exclamative subordinate clause, respectively, whereas (3) - exemplifying a surprise negation sentence - cannot appear in this context (cf. 3a). Accordingly, Snegs may be introduced by a discourse-marker expressing surprise or hesitation (called an expletive element by Greco), such as hát 'well' or erre 'then' (see (3)), but cannot contain the complementizer hogy 'that' often found in wh-exclamatives that are not embedded but appear as matrix clauses $(4 \mathrm{~d})$.

(4) a. *Hihetetlen, hogy (hát) János nem el olvasta a könyvet?! incredible that well John not PRT read.PAST.3SG the book.ACC intended: 'It is incredible that John read the book!'

b. Azt kérdezte, hogy János el olvasta-e a könyvet. that.ACC ask.PAST.3sG that John PRT read.PAST.3sG-Q the book.ACC 'She asked whether John had read the book.'

c. Hihetetlen, hogy János miket el (nem) olvasott! incredible that John what.PL.ACC PRT not read.PAST.3sG 'It is incredible what surprising things John has read!'

d. (Hogy) János miket el (nem) olvasott! that John what.PL.ACC PRT not read.PAST.3SG 'What surprising things John has read!' 
Another element that often appears in Snegs both in Italian and Hungarian is an ethical dative (Greco 2019a). ${ }^{3}$ In Hungarian, ethical datives usually refer to the speaker, appearing in the form of $1^{\text {st }}$ person singular and plural pronouns. Their distribution is not restricted to Snegs, they can also appear in interrogatives, imperatives, indicatives, as well as wh-exclamatives (5b). ${ }^{4}$

a. (Hát) Mari nem el törte
well Mekem
'Mary broke her arm on me! (surprisingly)'

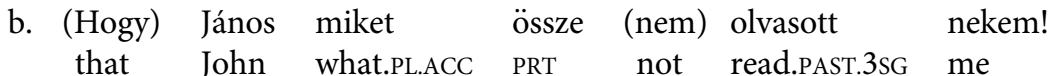
'What surprising things John has read on me!'

As far as semantics and pragmatics are concerned, Snegs are factive sentences which express the speaker's surprise over the occurrence of events that were previously thought to be unlikely to happen (Greco 2019a). The negation they contain differs from standard negation in that it is always interpreted as expletive, i.e. truth-functionally irrelevant, which is reflected in its syntactic properties as well (see section 3.2 for a detailed discussion). Nevertheless, negation in Snegs is not completely devoid of meaning: we follow Delfitto, Melloni \& Vender (2019) and Greco $(2018,2019 \mathrm{ab})$ in arguing that it interacts with the presuppositional layer of meaning, negating the presupposition that the event denoted by the proposition is a member of the set of events likely to be true. In other words, negation in Snegs expresses the speaker's counterexpectation.

The type of sentence that Snegs resemble most in Hungarian at first sight is a question containing external negation, discussed by Gyuris (2016) and exemplified by (6a). In the remainder of this subsection, we consider the extent of similarity and the substantial differences between the two structures, and we argue that Snegs are fundamentally different from externally negated questions.

As far as the syntactic position of the negator is concerned, Snegs and externally negated questions are comparable, since both contain a non-inverted verbal particle - verb unit preceded by an overt negator (6), a construction rarely found in Hungarian. This similarity, however, only concerns negation, and does not tell us whether Snegs are indeed interrogatives.
a. (Hát) János nem el utazott? (externally negated question) well John not PRT travel.PAST.3SG
'Was it not our common knowledge that John has travelled away?'
b. (Hát) János nem el utazott?! (surprise negation sentence) well John not PRT travel.PAST.3SG
'John travelled away! (surprisingly)'

\footnotetext{
${ }^{3}$ Ethical datives are "non-argumental (clitic) pronouns that pick out a person, either the speaker or the hearer, who emotionally participates in the event expressed by the sentence" (Greco 2019a, section 2.2).

${ }^{4}$ For a general discussion of ethical datives in Hungarian, see Rákosi (2008).
} 
Snegs are similar to interrogatives is that they can be answers to questions and they themselves can be answered (cf. Greco 2019a). In a context (borrowed from Gyuris (2016)) where a meeting is about to start that the organizer expected János to attend, but for which he did not turn up, (6a) would be a perfectly fine answer to the organizer's inquiry about the whereabouts of János. To (6a), other participants could give both a positive and a negative answer, thus confirming or disproving the shared assumption that János went on a holiday.

Similarly, in a narrative context where the speaker went to visit János, expecting him to be at home but did not find him there, (6b) can serve as an answer either to a general inquiry from the listener ('What happened?'), or a rhetorical question posed by the speaker such as 'And what did I see when I got there?'. However, when it comes to an answer, the similarity between (6a) and (6b) ends, because Snegs can only be followed by an affirmative, typically uttered by the speaker themself, such as De. (meaning 'He did indeed').

This leads us to a crucial semantic difference between Snegs and interrogatives, namely, that Snegs are factive. Factivity is a property which sets Snegs apart from questions but connects them to exclamatives (Greco 2019a; Portner \& Zanuttini 2000). While (6b) implies that (contrary to the speaker's expectations) János did indeed travel somewhere, externally negated questions simply ask for information, and do not contain such a strong truthconditional commitment. (6a) is compatible with different states of affairs in which János is not present at the meeting because he is either on holiday, in the mall, or in fact sick at home.

In addition to this semantic difference, some syntactic properties of Snegs also differ from that of interrogatives. Externally negated questions can, at least in the language variety of some Hungarian speakers (hence the \% sign), contain the interrogative particle $-e$, adjoined either to the verb (7a) or the negator itself (7b), which is completely ruled out in Snegs (7c). Ethical datives are, on the other hand, only licensed in Snegs and not in externally negated interrogatives (see (5b) above and (7d) below):

a. Nem tudom, hogy Mari nem el utazott-e. not know.1sG that Mary not PRT travel.PAST.3SG-Q 'I wonder if Mary is not supposed to have travelled away.'

b. \%Mari nem-e el utazott? Mary not-Q PRT travel.PAST.3SG

'Is it not our common knowledge that Mary travelled away?'

c. Hát Mari nem( $\left.{ }^{*}-\mathrm{e}\right)$ el $\operatorname{utazott}\left({ }^{*}-\mathrm{e}\right)$ ?! well Mary not-Q PRT travel.PAST.3SG-Q intended: 'Mary travelled away (surprisingly)!'

d. Mari nem el utazott *nekem? Mary not PRT travel.PAST.3SG me intended: 'Is it not our common knowledge that Mary travelled away on me?'

${ }^{5}$ Wh-exclamatives, on the other hand, can neither be answered, nor given as answers to questions. 


\subsection{Negation in surprise negation sentences}

This section discusses how negation in Snegs differs from standard (truth-functionally active) negation in Hungarian. The key concepts in answering this question will be (i) the word order of the sentence, (ii) negative concord and polarity phenomena in general, and (iii) the distribution of standard and expletive negative constructions.

The first difference concerns word order. Following É. Kiss (2009a) and Olsvay (2000), we assume that when a Hungarian sentence is negated, the negator is merged as the head of NegP, and the verb undergoes operator-induced movement to the head position of a functional projection called the non-neutral phrase (NNP). This results in word order changes: the order of the verb and its verbal particle is inverted, producing the following pattern: Neg $+\mathrm{V}+$ PRT. $^{6}$ Crucially, this inversion is missing from Snegs: in (8a) the negator is followed by the verbal particle and the verb, remaining in the order otherwise found in indicative (or neutral) clauses, yielding a non-negative reading. If the inversion does take place, the only available reading is that of a question or an exclamation (depending on the intonation) containing standard sentential negation $(8 b)$ :
a. (Hát) János nem el olvasta
well John not PRT read.PAST.3SG the
a könyvet?! (expletive negation)
'John read the book! (surprisingly)'
b. János nem olvasta el a könyvet ? / ! (standard negation)
John not read.PAST.3SG PRT the book.ACC
'Did John not read the book? / John did not read the book!'

Furthermore, even though Snegs contain an overt negator, this negator does not affect the polarity of the clause, and is unable to license strong negative polarity items or minimizers, at the same time allowing positive ones in its scope (9a). This is unexpected, since negators in Hungarian generally work reversely (see (9b)).
a. Hát János nem el ütött
valakit
/ ${ }^{*}$ senkit?! (Sneg with EN) well John not PRT hit.PAST.3SG somebody.ACC / nobody.ACC
'John hit someone with his car! (surprisingly)'
b. János nem ütött el *valakit / senkit! (exclamation with SN) John not hit.PAST.3SG PRT somebody.ACC / nobody.ACC
'John did not hit anyone with his car.'

Finally, the distribution of EN and SN in Snegs is not complementary: we can have both constructions in the same sentence, exhibiting the aforementioned differences in meaning, NPIlicensing and word order. (10a) and (10b) contain an expletive and a normal negator, of which

\footnotetext{
${ }^{6}$ For an alternative account of the correlation between negation and word order see Surányi (2002). Since our analysis does not depend on the choice between these competing accounts, we will not elaborate on their merits and shortcomings here.
} 
only the latter is interpreted as negative, inducing verb-verbal particle inversion and licensing strong NPIs. Note that in (10b) the second nem is an instance of focus negation.
a. Hát Mari nem nem olvasott el semmit?! (EN, SN) ${ }^{7}$ well Mary not not read.PAST.3SG PRT nothing.ACC 'Mary did not read anything! (surprisingly)'
b. Hát nem nem JÁNOS vette fel a telefont?! (EN, SN) well not not John pick.PAST.3SG PRT the phone.ACC
'It was not John who answered the phone! (surprisingly)'

\subsection{The structural position of the negator in Snegs}

The aim of this section is to identify the syntactic position that the negator occupies in surprise negation sentences. We will narrow down the possible choices by examining where the negator is placed if the sentence contains one (or several) of the following: a topic, a sentence adverbial, a quantifier, focus, or standard negation.

Firstly, Snegs can contain one or several topicalized elements, all of which have to precede the negator nem (11). Negation cannot appear before or in between topics (for clarity, the topics are underlined):
a. (Hát) János nem el vesztette a kulcsát?! well $\overline{\text { John }}$ not PRT lose.PAST.3sg the key.3sG.ACC
b. *(Hát) nem János el vesztette a kulcsát?! well not John PRT lose.PAST.3sG the key.3sG.ACC
c. (Hát) János a kulcsát nem el vesztette?! well John the key.3sG.ACC not PRT lose.PAST.3sG
d. *Hát János nem a kulcsát el vesztette?!

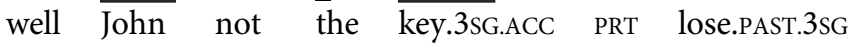 'John lost his keys! (surprisingly)'

\footnotetext{
${ }^{7}(10 a)$ could be used in a situation where Mary was expected to read a certain number of books/articles (by a given time) but did not read any, while (10b) means that although the speaker was absolutely sure that if (s)he dialled this number John would pick up, the phone was in fact answered by someone else. Such sentences sound a bit marked to some speakers, probably due to the juxtaposition of two phonologically identical and functionally similar elements. If a focused element intervenes, the markedness disappears (see also (13) later):
}

(i) Messi miatt vettem jegyet erre a meccsre,

Messi because buy.PAST.1SG ticket.ACC this.onto the game.onto

erre nem pont ma nem játszott?!

then not exactly today not play.PAST.3SG

'I bought a ticket to this game in order to watch Messi play, and then it was exactly today that he did not play! (surprisingly)' 
Snegs can contain sentence adverbials such as sajnos 'unfortunately' which are situated below TopP but above the functionally extended VP. If a surprise negation sentence contains such an adverbial, the negator appears between the adverbial and the predicate.
a. Hát sajnos nem le ejtettem a poharat?! well unfortunately not PRT drop.PAST.1SG the glass.ACC
b. *Hát nem sajnos le ejtettem a poharat? well not unfortunately PRT drop.PAST.1sG the glass.ACC 'Unfortunately I dropped the glass! (unexpectedly)'

Quantifiers, however, which are situated directly above the functionally extended VP, always follow the negator (13). This example also shows that (as we previously mentioned) Snegs can contain both EN and SN, as well as a focused element ${ }^{8}$ (indicated with capital letters). These observations will be crucial for our syntactic analysis of EN in Snegs because they rule out the possibility of a movement analysis.

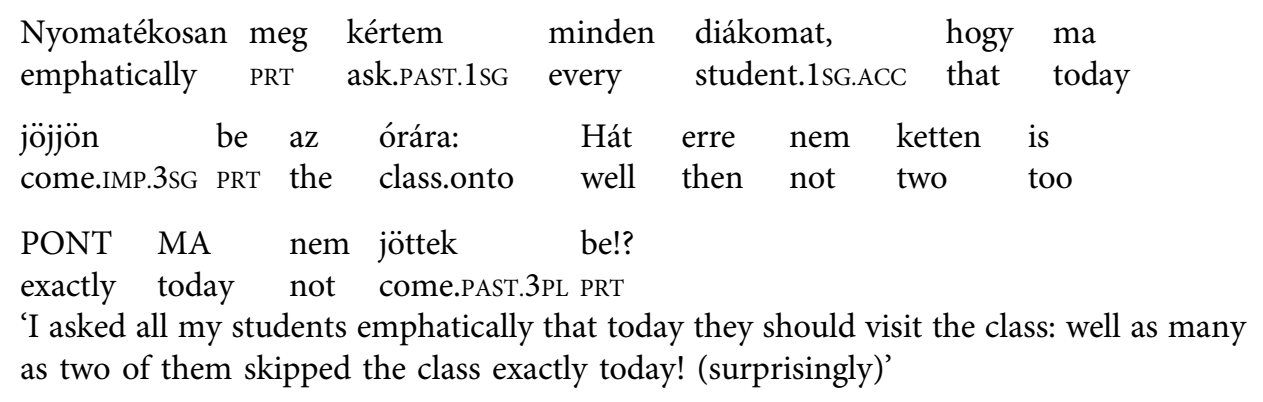

\subsection{The syntax of expletive negation in snegs}

As the previous section demonstrated, the expletive negator nem appears directly above the functionally extended VP in Snegs, which might be a QP, a FocP, a NegP or TP. Topics and sentence adverbials, on the other hand, both of which are situated in the topic field, must always precede the expletive negator nem. We will argue that similarly to Italian (Greco 2019a), nem in Hungarian Snegs is externally merged outside the functionally extended VP, identifying its position as the head of a projection called Speaker Deixis Phrase (SDP) (É. Kiss 2009b; Egedi 2009; Haegeman 2006; Tenny 2000). But before outlining our proposal, let us consider a few possible alternative analyses.

Firstly, we might assume that nem in Snegs is simply adjoined to the left edge of the extended VP, which has been proposed by Surányi (2002) for sentences containing focus negation or metalinguistic negation, such as (14a). This assumption might appear reasonable, since both MN and EN fail to license strong NPIs, allow PPIs, and fail to trigger verb-verbal modifier inversion (14b). However, as Gyuris (2016) pointed out in connection with externally

\footnotetext{
${ }^{8}$ In Hungarian, there is at most one FocP in the left periphery of the sentence (see (19) below).
} 
negated questions, if we were to analyze EN as adjunction, it would be possible to place the negator before (one or both of) the topic(s), which is indeed possible in MN constructions (14c), but completely out in Snegs (14d). ${ }^{9}$ Note that János 'John' is a topic here, not a focused element.

a. Nem be ment $\begin{array}{llll}\text { hozzájuk, hanem } & \text { levelet } \text { küldött }^{10} \\ \text { not } & \text { PRT gO.PAST 3SG to.them }\end{array}$ 'He did not drop by them, but sent a letter to them instead'

John not PRT call.PAST.3SG somebody.ACC / nobody.ACC

hanem föl hívott valakit / *senkit.

but.rather PRT call.PAST.3sG somebody.ACC / nobody.ACC

'John did not call someone, he called someone.'

c. Nem János fel hívott valakit, not John PRT call.PAST.3SG somebody.ACC

hanem János föl hívott valakit.

but.rather John PRT call.PAST.3SG somebody.ACC

'It is not the case that John called someone, rather, John called someone.'

d. *Hát nem János fel hívott valakit?! well not John PRT call.PAST.3sG somebody.ACC intended: 'John called someone! (surprisingly)'

Another option would be to propose that nem in Snegs is not only predicate-external, but is in fact situated in a silent matrix clause. This line of reasoning was used by several authors to account for other instances of non-standard negative constructions in Hungarian, such as nem mintha 'not that' clauses (Turi 2015), clauses with nehogy 'not.that' (É. Kiss 2015), externally negated questions (Gyuris 2016) or "affirmatives disguised as negated questions" (Simonyi 1902). The first problem with this possibility is that nem in Snegs does not license weak NPIs. If nem was indeed in a higher clause, the requirements of weak NPI licensing would clearly be met (Tóth 1999), thus we would expect to find weak NPIs such as valaki is 'anyone+too' in its complement clause. This is, crucially, not the case. While weak NPIs are acceptable in the first two of the above-mentioned cases (15a) and (15b), they are disallowed in Snegs (15c). The other problem is that Snegs cannot be introduced by a real complementizer such as hogy or mintha, and are, in fact, unembeddable (see 4 above). Because of this, the possibility of an elliptical superordinate clause in Snegs can be excluded.

$\begin{array}{lllllll}\text { a. Nem mintha Mari el olvasott } & \text { volna } & \text { valamit } & \text { is... } \\ \text { not as.if } & \text { Mary PRT read.PAST.3SG } & \text { be.COND.3SG } & \text { something.ACC } & \text { too } \\ \text { 'Not that Mary has read anything at all...' } & & \end{array}$

\footnotetext{
${ }^{9}$ In addition to this, Snegs also lack the corrective flavour evident in case of metalinguistic negation.

${ }^{10}$ Surányi $(2002,115)$.
} 
b. Nehogy el olvass valamit is! not.that PRT read.IMP.2SG something.ACC too 'Don't you by any means read anything!'

$\begin{array}{lllllll}\text { c. Hát } & \text { Mari } & \text { nem } & \text { el } & \text { olvasott } & \text { valamit } & * \text { is! } \\ \text { well } & \text { Mary } & \text { not } & \text { PRT } & \text { read.PAST.3SG } & \text { something.ACC } & \text { too }\end{array}$ intended: 'Mary read something! (surprisingly)'

This leads us to entertain the possibility that nem in Snegs is not simply adjoined to the appropriate functional projection, but occupies a dedicated position which is predicate-external but clause-internal. Our analysis thus will be similar to, but not identical with the proposal of Greco (2019a), developed for Snegs in Italian: we will argue that in Hungarian too, the negator in Snegs is not moved from VP to a higher projection (cf. Zovko Dinković \& Ilc 2017; Abels 2005), but rather, it is is externally merged in CP. What makes a movement analysis in the case of Hungarian Snegs explicitly untenable is the co-occurrence of standard and expletive negation, exemplified by (10) above. One point where our analysis departs from Greco's is that unlike Italian, Hungarian allows focused elements in Snegs (see 10 and 13 above), which precludes the possibility that the whole VP would be focused here (2019a).

Before we elaborate the details of our proposal, it will be useful to have a closer look at the syntax of adverbials in Hungarian. Following É. Kiss (2009b) and Egedi (2009), we differentiate between two zones of adverbials: sentence adverbials (higher adverbials) and predicate adverbials (lower adverbials). As shown by É. Kiss (2009b) and Egedi (2009), various tests such as stress assignment and the relative position wrt topics e.g. indicate that the latter are part of the predicate (TP) why the former are predicate-external, being part of the topic zone (so much so that topics and sentence adverbials can be freely interspersed with one another). The relative order of adverbials within each zone largely follows the universal order proposed by Cinque (1999). We follow É. Kiss (2009b) in assuming that adverbials are adjuncts (Ernst 2002), although nothing hinges on this as far as our proposal here is concerned. Also, we assume with É. Kiss (2009b) and Egedi (2009) that there is a functional layer called the Speaker Deixis Phrase (Haegeman 2006; Tenny 2000) on top of TP, responsible for introducing the point of view of the speaker as a deictic, sentient argument. Consider:

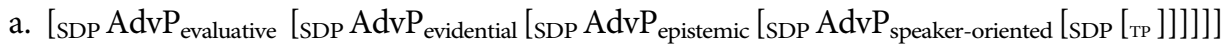
b. [те $\left.\operatorname{AdvP}_{\text {frequency }}\left[\mathrm{TP} \operatorname{AdvP}_{\text {manner }}\left[\mathrm{TP} \operatorname{AdvP}_{\text {degree }}[\mathrm{TP}]\right]\right]\right]$

Earlier, we have seen that the relative order with quantifiers, focus and standard negation indicates that the negator in Snegs is predicate-external. This is further corroborated by the observation that it obligatorily precedes predicate adverbials (such as the aspectual adverbial in $(17 \mathrm{a}, \mathrm{b})$ and the degree adverbial in $(17 \mathrm{c}, \mathrm{d}))$ :
a. Hát János nem rögtön le well John not at.once PRT
ejtette drop.PAST.3sG
a tányért!?
the plate.ACC
b. *Hát János rögtön nem le
ejtette
a tányért!?
well John at.once not PRT drop.PAST.3SG the plate.ACC
'John dropped the plate at once! (surprisingly)' 


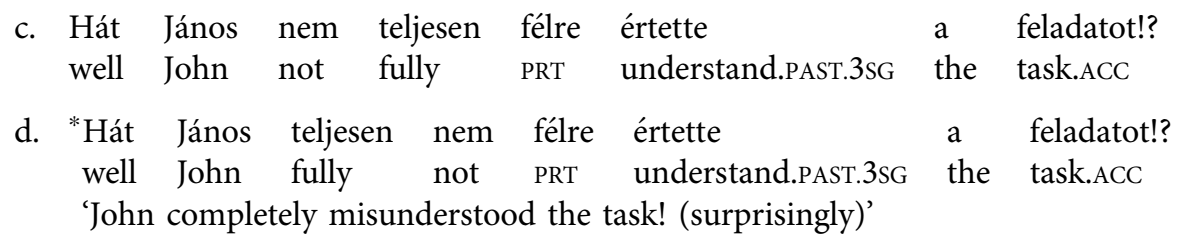

As far as sentence adverbials (such as the evaluative adverb in (18a, b) and the speaker-oriented adverb in $(18 \mathrm{c}, \mathrm{d})$ are concerned), they are obligatorily followed by the expletive negator:
a. Hát János sajnos
nem megint
össze
törte well John
unfortunately
not
again
PRT
break.PAST.3SG
a kocsit!?
b. *Hát János nem sajnos
megint
össze törte
the
car.ACC
well John not
unfortunately again
PRT
break.PAST.3sG
a kocsit!?
'Unfortunately John smashed the car again!'
c. Hát János taktikusan nem mindenkire rá borította az asztalt!? well John cleverly not e'one.to PRT topple.PST.3SG the table.ACC
d. *Hát János nem taktikusan mindenkire rá borítototta az asztalt!? well John not cleverly everyone.to PRT topple.PST.3sG the table.ACC 'Cleverly, John insulted everyone!' (ironic)

The expletive negator in Snegs is predicate-external but obligatorily follows topics and sentence adverbials. Recall that the Speaker Deixis Phrase is exactly in this zone. According to Haegeman (2006, 1663): "SD is a functional layer required to anchor a proposition to a speaker", inasmuch as it "introduce[s] the point of view of the speaker, and [...] the speaker as a sentient, deictic argument" (Tenny 2000, 319). Note that according to Delfitto, Melloni \& Vender (2019), the expletive negator expresses a strong speaker-oriented evaluation (that the speaker considers the asserted proposition unexpected and surprising).

Additionally, Snegs have a special illocutionary force (they are assertions yet have a mixed exclamative-question prosodic contour). As pointed out by Egedi $(2009,113)$, "[s]peaker deixis may also host 'force' features (declarative, question, etc.) in Hungarian". Since the expletive negator expresses speaker-oriented evaluation and it is an obligatory (even defining) element of Snegs, which are differentiated by their special illocutionary force, it is reasonable to propose that the expletive negator is merged in the head position of SDP. ${ }^{11}$

\footnotetext{
${ }^{11}$ Gärtner \& Gyuris (2012) criticize certain aspects the SDP-proposal and advocate a return to ForceP, or more precisely, TypeP, with TypeP located above TopP. Discussing the relative merits of both proposals is beyond the scope of this paper, yet we wish to point out the the gist of our proposal might carry over to the TypeP framework as well. While Gärtner \& Gyuris (2012) assume that TypeP is above TopP, no syntactic or semantic evidence is provided to support this and in fact, the exact position of TypeP on the left periphery appears to be immaterial to their proposal: it appears to us that TypeP might as well be in the exact same position as SDP in our proposal. Since the expletive negator in Snegs is closely entwined with clause typing, Type ${ }^{0}$ might reasonably be assumed to host it.
} 


$$
\left[\left\{\text { TopP }^{*} \mid \operatorname{AdvP}_{\text {sentence }}\right\}[\text { SDP nem [QP [FocP [NegP [TP ... ] ] ] ]]] }\right.
$$

Our proposal bears some resemblance to previous proposals that assumed that expletive negation involves a negative evaluation and is connected to the higher evaluative layer of CP. (Abels 2005; Yoon 2011; ${ }^{12}$ Dinković \& Ilc 2017). Abels (2005) specifically assumes that in expletive negation in Russian embeded sentences, the negator is merged in the standard negation position (within TP) and it is later moved to CP-layer at LF in order to take scope over an evaluative head, in order to flip a positive or neutral evaluation into a negative one.

However, our proposal diverges in many crucial respects from these models. First, we have shown that in Snegs, the expletive negator is base-generated in its TP-external position: there is no movement involved. Secondly, the expletive negator is in the lowest possible slot in the CPlayer, below any evaluative heads: its function is not the flipping of the evaluative force but rather, the negation of a presupposition (which, of course, does express a strong evaluation as to the unexpectedness of the proposition). Finally, while in Snegs, the negator is overtly in the CPlayer, in other cases of expletive negation (such as in wh-exclamatives), it is TP-internal and there is no evidence of any covert movement taking place (see section 4).

\subsection{The meaning of EN in Snegs}

As Greco (2019a) points out, Snegs have a surprise effect because they denote unlikely or unexpected events. In other words, they express the speaker's surprise over the occurrence of events that were previously thought by them to be unlikely to happen. They are, therefore, infelicitous in contexts where the state of affairs presented is in fact expected or nothing out of the ordinary. This means that in a context such as (20a), (20b) is an acceptable utterance, while (20c) is completely incongruent.
a. Mari
rengeteget tanult
Mary lot.ACC study.PAST.3sG the
'Mary studied a lot for the exam.'
b. Hát erre nem meg bukott?!
well then not PRT stumble.PAST.3SG
'Well, she failed! (surprisingly)'
c. \#Hát erre nem át ment?!
well then not PRT go.PAST.3SG
'Well, she passed! (surprisingly)'

a vizsgára.

exam.onto

\footnotetext{
${ }^{12}$ In addition to a negative evaluation of likelihood and desirability, Yoon (2011) also characterizes the expletive negator as a subjunctive mood marker which indicates nonveridicality. Such an analysis cannot be extended to Hungarian, since the contexts under investigation here are clearly veridical (John read a book (surprisingly, unexpectedly)! entails John read a book.) For essentially the same reason, Makri's $(2013,62)$ proposal that "EN is actually an epistemic modal which denotes the attitude holder's/speaker's lack of evidence regarding the truth of the complement clause" also cannot hold for the data under investigation (note also that Makri's proposal does not cover root clause expletive negation).
} 
We follow the proposal of Delfitto, Melloni \& Vender (2019) in arguing that what expresses the speaker's counter-expectation in Snegs is the expletive negator. More precisely, the role of EN is to deny the presupposition that the event denoted by the proposition is a member of a set of events likely to be true (Delfitto, Melloni \& Vender 2019). Their argument is based on the "Question-Under-Discussion" approach of von Stutterheim \& Klein (1989), in which each utterance in the discourse addresses a(n explicit or implicit) question, and the answer provided is picked out of a presupposed focus-set of potential (contextually relevant) answers. According to Delfitto, Melloni \& Vender (2019) in the case of Snegs, this focus-set contains events and statesof affairs that are likely to be true, and what EN does is express that the event denoted is not a member of the set. In the context above (20a), the chances of Janos failing the exam were significantly low - but contrary to expectations, this is what happened, which strikes us as surprising. This contrast between expectations and actual state of affairs is what EN in Snegs draws attention to. Thus EN works on the level of presuppositions and not the asserted meaning, which dovetails nicely with our syntactic analyis, in which the expletive negator is positioned not in NegP (the locus of truth-conditional negation) but rather in SDP, a projection responsible for speaker-anchored evaluation.

\section{EXPLETIVE NEGATION IN WH-EXCLAMATIVES}

\subsection{EN in wh-exclamatives: the main facts}

Wh-exclamatives (cf. Lipták 2006) contain a wh-expression and express surprise, disbelief or incredulity with regard to the proposition on the speaker's side:

$$
\begin{aligned}
& \text { János miket } \quad \text { el olvasott! } \\
& \text { John what.PL.ACC PRT read.PAST.3SG } \\
& \text { 'What (surprising, unexpected) things John has read!' }
\end{aligned}
$$

(21) above, in addition to asserting that John has read something, also expresses that the speaker is surprised (or even finds it difficult to believe) that John has indeed read the things that he has read. As noted by Lipták (2006) a.o., all wh-exclamatives in Hungarian (similarly to other languages, cf. 31 below) are such that they can optionally be introduced by the complementizer hogy 'that':

$$
\begin{aligned}
& \text { (Hogy) János miket el olvasott! } \\
& \text { that John what.PL.ACC PRT read.PAST.3SG } \\
& \text { 'What (surprising, unexpected) things John has read!' }
\end{aligned}
$$

Crucially for our purposes, a well-defined subset of wh-exclamatives can also optionally contain an expletive negator:

$$
\begin{aligned}
& \text { (Hogy) János miket } \quad \text { el } \quad \text { (nem) } \\
& \text { that John whatt! } \\
& \text { 'What (surprising, unexpected) things John has read!' }
\end{aligned}
$$


In terms of word order, it is striking that there is no verb-verbal particle inversion ${ }^{13}$ in (23). This suggests that unlike in wh-questions, which in Hungarian involve the focusing of the wh-phrase (24a), in wh-exclamatives with (optional) expletive negation, no FocP is involved: while the whexpression is fronted to some position (see discussion later), it is not FocP (which would induce verb movement):
a. [TopP János [FocP miket [NNP olvasott [TP el endest]]? John what.PL.ACC read.PST.3SG PRT
'What (things) has John read?'

b. [TopP János [X miket [ $[\mathrm{TP}$ el olvasott John what.PL.ACC PRT read.PAST.3SG

'What (surprising, unexpected) things John has read!'

The lack of inversion also suggests that there is no standard negation involved (with NegP). Consider:

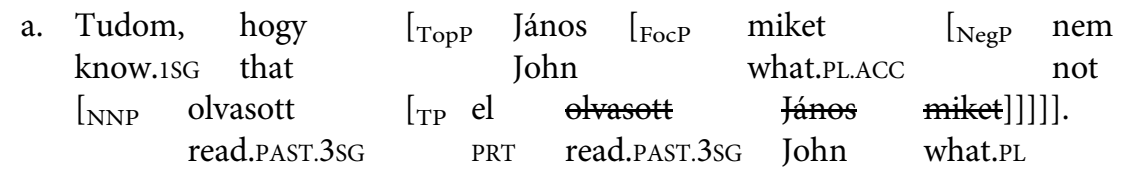

'I know what (things) John has not read.'

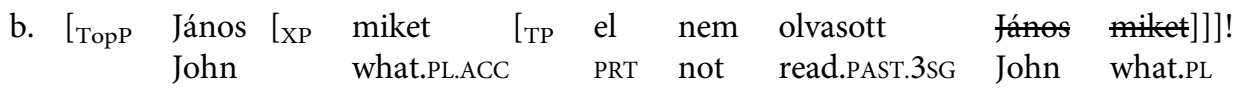
'What (surprising, unexpected) things John has read!'

However, unlike in SNEGS, nem in wh-exclamatives is in a lower position, wedged between PRT and $\mathrm{V}$ :
a. (Hát) [Topp János [SDP nem [TP el olvasott könyvet]]]!? well John not PRT read.PAST.3SG John a book.ACC 'John read a book! (surprisingly)'
b. (Hogy) [TopP János [xp miket [TP el nem olvasott that John what.PL PRT not read.PAST.3sG John what.PL 'What (surprising, unexpected) things John has read!'

\footnotetext{
${ }^{13}$ In neutral sentences (i.e., sentences lacking both focusing and standard negation) in Hungarian, the word order is PRT $\mathrm{V}$. The standard analysis of these sentences is that the verbal particle occupies SpecTP (or SpecAspP or SpecPredP) and the verb occupies the $\mathrm{T}^{0}$ (or Asp ${ }^{0}$ or $\mathrm{Pred}^{0}$ ) head position. If either focusing or standard negation is present, the verb is obligatorily moved (either to $\mathrm{Foc}^{0} / \mathrm{Neg}^{0}$, or to $\mathrm{NN}^{0}$, on which see the discussion above in Section 3.2) while the verbal particle remains in place: this results in inversion and a V PRT surface order. Q-raising or topicalization do not induce verb movement (and, as a consequence, they also do not induce verb-verbal particle inversion). For a more detailed recent overview of the various proposals wrt the syntax of the verbal particle in Hungarian, see Halm (2021, Section 9).
} 
There are two constraints on the optional availability of EN in wh-exclamatives. The first concerns the distinction between external and internal scalarity, as defined by Nouwen \& Chernilovskaya (2015). In the case of external scalarity, an event is being compared to other alternative events (on a scale of likelihood / expectedness):

$$
\begin{aligned}
& \text { (Hogy) mik meg történnek! } \\
& \text { that what.PL PRT happen.3PL } \\
& \text { 'What surprising things happen!' }
\end{aligned}
$$

In the case of internal scalarity, the comparison of the wh-referent is instantiated on a scale of some property:

$$
\begin{aligned}
& \text { (Hogy) milyen ügyesen fel mászol a fára! } \\
& \text { that how deftly PRT climb.2sG the tree.onto } \\
& \text { 'Just how deftly you climb the tree!' }
\end{aligned}
$$

EN is optionally available in wh-exclamatives expressing external scalarity but not in whexclamatives expressing internal scalarity:
a. (Hogy) mik meg nem történnek!
that what.PL PRT not happen.3PL
'What surprising things happen!'

b. (Hogy) milyen ügyesen fel (*nem) mászol a fára! that how deftly PRT not climb.2sG the tree.onto intended: 'Just how deftly you climb the tree!'

The other constraint is that expletive negation is degraded unless a non-episodic (possibly universal or generic) reading is accessible:
a. ?*(Hogy) mi meg nem történt
that what PRT not happen.PST.3SG

$\begin{array}{llll}\text { tegnap reggel } & 10-k o r & \text { a } & \text { szomszédban! } \\ \text { yesterday morning } & 10 . \text { at } & \text { the neighbour.in }\end{array}$
intended: 'What a surprising thing happened yesterday moring at 10 at the neighbours!'
$\begin{array}{cllll}\text { b. ?(Hogy) } & \text { mi } & \text { meg } & \text { nem } & \text { történik! } \\ \text { that } & \text { what } & \text { PRT } & \text { not } & \text { happen.3sG }\end{array}$
'What surprising things happen!' / ?*‘ What a surprising thing happened!'
c. (Hogy) mik meg nem történnek! that what.PL PRT not happen.3PL
'What surprising things happen!'


d. (Hogy) mi minden meg nem történik!

that what all PRT not happen.3sG

'What surprising things happen!'

e. (Hogy) mi meg nem történik manapság!

that what PRT not happen.3sG these.days

'What surprising things happen these days!'

In (30a), only an episodic reading is available. (30b) to be can get either an episodic or a generic reading: it is acceptable on the latter reading but unacceptable (or at least very marked) on the episodic reading. In (30c), the wh-expression is pluralized, yielding a quantified expression. In (30d), the wh-expression is combined with the quantifier minden 'every' (cf. Bartos (2020) on this construction). In (30e), the adverbial manapság 'these days' yields a generic statement. A similar constraint is discussed by Delfitto, Melloni \& Vender (2019) with regard to Italian (cf. also Zanuttini \& Portner (2000)):

a. Che cosa mi ha detto Gianni!

'Gianni told me something and this was surprising!'

b. Che cosa non mi ha detto Gianni! what to.me not has told Gianni

'Gianni told me everything and this was surprising!'

Delfitto, Melloni \& Vender (2019) observe that (31a) is interpreted episodically ('Gianni has told me one particular surprising thing.') whereas (31b) is interpreted quasi-universally ('Gianni has told me every surprising thing you could imagine, and more.') Note that in contrast to Hungarian, Italian does not have pluralized wh-expressions or the 'wh-expression + all' construction. This means that in Italian, a simple wh-expression can be interpreted both episodically and quasi-universally ((31a) and (31b)).

The situation is slightly different in Hungarian: here, speakers have the option to indicate that a wh-expression is to be interpreted quasi-universally by employing morphosyntactic means: pluralization or the 'wh- + all' construction. This means that in the case of a plain whexpression, a quasi-universal reading is less accessible, which leads to the degradedness of (31b).

Lipták (2006) noted that wh-exclamatives in Hungarian can be embedded under exclamative predicates. Lipták (2006) makes this observation with regard to wh-exclamatives without EN (in fact, EN is not discussed at all in Lipták (2006)), however, it is valid in the case of EN as well:

$$
\begin{aligned}
& \text { Elképesztő, hogy mik meg (nem) történnek manapság. } \\
& \text { astonishing that what.PL PRT not happen.3PL nowadays } \\
& \text { 'It is astonishing what (surprising, unexpected) things happen these days!' }
\end{aligned}
$$

\subsection{EN in wh-exclamatives: syntactic analysis}

Following Lipták (2006), we analyze wh-exclamatives in Hungarian as root clauses with an optionally filled complementizer position: 


$$
\begin{aligned}
& \text { [CP (Hogy) [TopP János [XP miket [Tт el olvasott } \\
& \text { that John what.PL.ACC PRT read.PAST.3SG John what.PL.ACC } \\
& \text { 'What (surprising, unexpected) things John has read!' }
\end{aligned}
$$

Based on word-order facts and other observations, Lipták (2006) proposes three different positions for the wh-expressions. In those cases where there is obligatory PRT-V inversion, the whexpression is taken to occupy FocP:

$$
\begin{aligned}
& \text { [CP (Hogy) [FocP kivel [ }{ }_{\text {TP }} \text { futottam össze tegnap]]]! } \\
& \text { that who.with run.PAST.1SG PRT yesterday }
\end{aligned}
$$

'Who I bumped into yesterday!' (episodic, one particular person)

In the limited number of cases where PRT-V inversion is categorically impossible, the wh-expression is taken to occupy the position of completion/intensity adverbs:

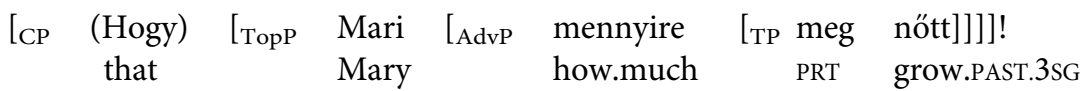

'How much Mary has grown!'

The third scenario involves wh-expressions where both word orders (with or without inversion) appear to be available, with subtle interpretive differences. Lipták (2006) proposes that expressions such as hány 'how many' may occupy either a quantifier position $\left(\mathrm{QP}^{14}\right)$ or a focus position (FP):

$$
\begin{aligned}
& \text { a. [TopP János [QP hány könyvet [TP meg vett]]]! } \\
& \text { John how.many book.ACC PRT buy.PAST.3SG } \\
& \text { 'How many books John has bought!' } \\
& \begin{array}{llllll}
\text { b. [TopP } & \text { János [FocP } & \text { hány } & \text { könyvet } & \text { [TP vett } & \text { meg] }] !^{15} \\
& \text { John } & \text { how.many } & \text { book.ACC } & \text { buy.PAST.3SG } & \text { PRT }
\end{array} \\
& \text { 'How many/few books John has bought!' }
\end{aligned}
$$

The different word orders are due to the fact that focusing induces verb movement but Q-raising does not.

Crucially for our purposes, Lipták (2006) proposes that quantificational wh-expressions such as $k i$ minden 'who all' and plural wh-expressions such as kik 'who-PL' on a

\footnotetext{
${ }^{14}$ Lipták (2006) calls this projection many-P in order to exactly pinpoint its position within the articulated quantifier field and differentiate it from another quantifier projection (DistP). For our purposes, this difference plays no role and for simplicity, we label this position as QP.

${ }^{15}$ To the authors of the present paper, such sentences (with inversion) sound quite marked as wh-exclamatives, and are only acceptable if parsed as rhetorical questions. However, since these sentences and their potential analyses are irrelevant for this paper, we do not pursue this issue further.
} 
quantificational reading $^{16}$ (Link 1983) occupy QP and are thus associated with straight word order (lack of PRT-V inversion). We propose that this class should be slightly broadened and taken to also include singular wh-expressions on a generic reading (see (30) above). With this slight extension, Lipták's (2006) proposal, together with our observation that EN in whexclamatives is available exactly in those cases where the wh-expression is interpreted quantificationally/generically; explains rather nicely why wh-exclamatives with EN obligatorily have the straight word order (no PRT-V inversion):

$$
\begin{aligned}
& \text { [CP (Hogy) [TopP János [QP miket [TP el nem olvasott]]]! } \\
& \text { that John what.PL.ACC PRT not read.PAST.3sG }
\end{aligned}
$$

'What (surprising, unexpected) things John has read!'

The next question is the position of the negator, something which Lipták (2006) does not discuss. As we have seen, in wh-exclamatives, the expletive negator appears to be TP-internal and it is wedged between the PRT and V. Because of this, and because of the lack of PRT-V inversion, it clearly cannot be in NegP. Our proposal is that instead of heading its own projection (as in NegP) or occupying the head position of a dedicated projection (SDP in the case of Snegs), in wh-exclamatives, the expletive negator is adjoined to the $\mathrm{T}$ head:

$$
\begin{aligned}
& \text { [CP Hogy [TopP János [QP miket [TP el [T' [T nem olvasott]] [VP ]]]]]]! } \\
& \text { that John what.PL.ACC PRT not read.PAST.3sG }
\end{aligned}
$$

'What (surprising, unexpected) things John has read!'

In fact, É. Kiss $(2014,2015)$ proposed the same structure to account for the word order properties of Standard Negation in Old Hungarian (see also Gugán 2017, 2018, 2020):

De áldott $\begin{gathered}\text { Krisztus } \\ \text { but blessed }\end{gathered} \begin{aligned} & \text { Christ no hí } \\ & \text { never faithful man.DAT }\end{aligned}$ heart.3sG.ACC
meg nem keményíti.
PRT not (Jókai Codex 51-52)
'But Christ the blessed shall never harden the heart of a faithful man.'

This lower negation position was dominant until the Middle Hungarian period but it was then supplanted by the higher negation position $(\mathrm{NegP})$ in a series of developments that can be characterized as a negative cycle.

${ }^{16}$ Consider the sentences below, where $k i k$ has a non-quantificational reading in (i) and a quantificational reading in (ii):

(i) (Hogy) kikkel futottam össze tegnap: Barack és Michelle Obamával! that who.with run.PAST.1SG PRT yesterday Barack and Michelle Obama.with 'Who I bumped into yesterday: Barack and Michelle Obama!'

(ii) (Hogy) kikkel össze (nem) futottam tegnap: Barack és Michelle Obamával, that who.with PRT not run.PAST.1SG yesterday Barack and Michelle Obama.with Joe és Jill Bidennel, szinte mindenkivel, akit el tudsz képzelni! Joe and Jill Biden.with almost everyone.with who.ACC PRT can.2SG imagine.to 'Who all I bumped into yesterday: Barack and Michelle Obama, Joe and Jill Biden, almost everyone you can imagine.' 
É. Kiss (2014) also proposes that the expletive negator in until-clauses in Modern Hungarian occupies this position: ${ }^{17}$

Nem kapsz tortát,
not get.2sG cake.ACC
amíg meg nem eszed a brokkolit.
until PRT not eat.2SG the broccoli.ACC
'You won't get any cake until you eat the broccoli.'

Note that it is cross-linguistically not unusual that within the course of a Negative Cycle, the old, abandoned morphosyntactic configuration is repurposed as the locus of EN. Perhaps the bestknown example is French:
a. Elle ne vient.
(SN, Middle French)
she not come.3sG
b. Elle ne vient pas. (SN, conservative written Modern French) she not come.3sG NOT
c. Elle vient pas. (SN, colloquial Modern French) she come.3sg not
'She does not come.'
b. Je crains qu' elle ne vienne. (EN, Modern French)
I fear.1sG that she not come.suBJ.3sG
'I am afraid that she will come.'

It appears thus that Hungarian has passed a similar trajectory to French, and in the process, it switched type with regard to the the encoding of expletive negation. In many languages (e.g. Italian acc. to Delfitto, Melloni \& Vender (2019, 80-81)), SN and EN occupy the same morphosyntactic position and the interpretation of the negator as either $\mathrm{SN}$ or EN is a function of context and pragmatics. ${ }^{18}$ Gugán (2020) has argued that this was the case in Old H. As far as Modern Hungarian is concerned, however, EN and $\mathrm{SN}$ are associated with different morphosyntactic positions:

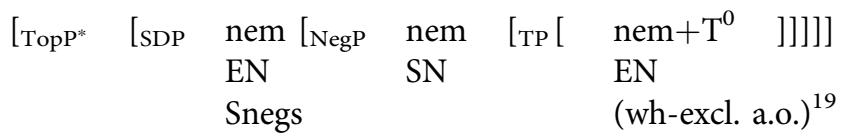

\footnotetext{
${ }^{17}$ Cf. also Ürögdi (2013) for a different analysis.

${ }^{18}$ Snegs appear to be special, though: it seems that they have a dedicated TP-external position, which sets them apart from standard negation and other types of expletive negation.

${ }^{19}$ Note that in our model of expletive negation in wh-exclamatives, we make no use of a silent DegP in the vein of Espinal (2000). Espinal (2000) assumes that expletive negators are NPIs in need of licensing by a non-veridical lexical head, and since Spanish and Catalan wh-exclamatives are non-embeddable and non-factive, the $\mathrm{C}$ head is not a suitable candidate. Crucially, however, we do not regard expletive negators as NPIs in need of licensing, and, incidentally, whexclamatives are embeddable and factive in Hungarian.
} 


\subsection{EN in exclamatives: semantics and pragmatics}

Of the various well-known semantic properties of exclamatives (see Lipták $(2006,374)$ for an overview, also Elliott (1974), Grimshaw (1979), Michaelis \& Lambrecht (1996)), the most important one for our purposes is that they invoke a set of alternative propositions (Zanuttini \& Portner 2003) and they convey a conventional implicature that the asserted proposition is on the top of a scale of alternative propositions in terms of noteworthiness or surprise factor (Portner \& Zanuttini 2000, 2003).

Consider a scenario where there is a set of things Mary might do for her students: $U=\{a, b$, c, ... z \}. Sentence (43) can be analyzed as follows:

$$
\begin{aligned}
& \text { Mari miket meg nem tesz a diákjaiért! } \\
& \text { Mary what.PL.ACC PRT not do.3sG the student.3sG.PL.for } \\
& \text { 'What (extreme) things Mary does for her students.' } \\
& \text { Assertion: 'Mary does some things (e.g. } \mathrm{A}=\{\mathrm{a}, \mathrm{b}, \mathrm{c}\}) \text { for her students.' } \\
& \text { Invocation of alternative propositions of the form 'Mary does X for } \\
& \text { her students.', where } \mathrm{X} \in \wp(\mathrm{B}) \text {, where } \mathrm{A} \subseteq \mathrm{B} \subseteq \mathrm{U} \\
& \text { Implicature: 'Mary does A for her students.' }>\text { surprise 'Mary does X for } \\
& \text { her students.', where } \mathrm{X} \in \wp(\mathrm{B}) \text { and } \mathrm{X} \neq \mathrm{A}
\end{aligned}
$$

As far as the semantic-pragmatic import of expletive negation in wh-exclamatives is concerned, we adopt the proposal of Delfitto, Melloni \& Vender $(2019,62)$ that EN in general (with the exception of Snegs) "corresponds to pre-encoding implicature cancellation syntactically". Crucially, the implicature being cancelled is not the implicature of surprise/noteworthiness discussed above, but rather, the more traditional and general scalar implicature of informativeness. Consider:

$$
\begin{aligned}
& \text { Mari miket meg nem tesz a diákjaiért! } \\
& \text { Mary what.PL.ACC PRT not do.3sG the student.3sG.PL.for } \\
& \text { 'What (extreme) things Mary does for her students.' } \\
& \text { Assertion: 'Mary does some things (e.g. } A=\{a, b, c\}) \text { for her students.' } \\
& \text { Invocation of alternative propositions of the form 'Mary does X for her } \\
& \text { students.', where X } \in(\mathrm{C}) \text {, where A } \subseteq \mathrm{B} \subseteq \mathrm{U} \\
& \text { Implicature of noteworthiness/surprise: 'Mary does A for her students.' > } \text { surprise } \\
& \text { 'Mary does X for her students.', where X } \in \wp(\mathrm{C}) \text { and } \mathrm{X} \neq \mathrm{A} \\
& \text { Implicature of informativeness: Mary does not do any of the elements of UA = } \\
& \{\text { d,e,f... } \text { for her students. In other words, the set of what Mary does for } \\
& \text { her students is limited, it is a proper subset of U, all the things that Mary } \\
& \text { might do for her students. }
\end{aligned}
$$

The implicature of informativeness here essentially corresponds to the old observation of some implying not all: by asserting that 'Mary does some things for her students.', the speaker implies that the more informative proposition that 'Mary does everything for her students.' is not true. EN cancels this implicature, giving us the quasi-universal reading: Mary does more things for her students than one would expect, potentially even everything. 


\section{MAIN FINDINGS AND IMPLICATIONS}

To summarize, our main finding is that Hungarian has three distinct negation positions, each corresponding to a truth-reversal operation on a different level:

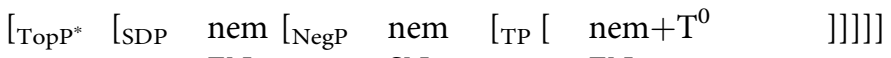

$$
\begin{aligned}
& \text { EN SN } \quad \text { EN } \\
& \text { Snegs (wh-excl. a.o.) }
\end{aligned}
$$

There is a clear mapping between syntax and semantics:

- A negator merged in High Negation position $\left(\mathrm{SDP}^{20}\right)$ encodes negation at the level of presuppositions: this yields Expletive Negation in surprise negation sentences (Snegs).

- A negator merged in the Middle Negation position (NegP) yields negation at the propositional level: this is Standard Negation.

- A negator merged in the Low Negation position (head-adjunction to $\mathrm{T}^{0}$ ) yields negation at the level of implicatures (Expletive Negation in wh-exclamatives, until-clauses etc.)

Furthermore, we have shown that in surprise negation sentences, an expletive negator in SDP can freely cooccur with a standard negator in NegP: this precludes any analysis of expletive negation in Snegs as a case of raising, and it also means that raising cannot be a general mechanism of expletive negation (cf. Abel's 2005 on Russian).

Also, we provided evidence that in Snegs in Hungarian, focusing is freely available: this means that Greco's (2019a) analysis of Snegs in Italian only partially carries over to Hungarian: while the negator is merged in what might be termed the extended topic field in both languages, the VP is not obligatorily focused in Hungarian (as opposed to Italian in Greco's (2019a) analysis.)

In general, we have found that the observation of Delfitto, Melloni \& Vender (2019) that expletive negation in Snegs differs from all other types of expletive negation in terms of semantic/pragmatic effect (negation on the presuppositional vs. the implicational level) is in fact clearly reflected in syntactic position: while the expletive negator in Snegs is merged high in the functional left periphery (SDP in the broader topic field), the expletive negator in all other cases is TP-internal, being head-adjoined to $\mathrm{T}^{0}$.

A limitation of this paper is that while the mapping between the various syntactic positions of Neg and its semantic-pragmatic import is clear, we offer no formal semantic model as to how these different effects are to be derived compositionally: this has to be left for later work.

\footnotetext{
${ }^{20}$ The question of whether the negator occupies a head or specifier position in SDP and NegP is not crucial to our proposal. As far as standard negation is concerned, some authors assume that the negator is in specifier position (e.g. Surányi 2002; É. Kiss 2008), while others assume that it is in a head positon (Olsvay 2000; Puskás 2000), yet others entertain the possibility of either option (É. Kiss 2009). Since we adopt a model where SN-induced verb movement targets $\mathrm{NN}^{0}$ (and not $\mathrm{Neg}^{0}$ ), $\mathrm{Neg}^{0}$ is available for housing the negator. There is also nothing to exclude the possibility of the negator being in $\mathrm{SD}^{0}$ in Snegs. Since the lowest negation position is a head position, it appears theoretically more appealing and simple to assume that the higher negation positions are also head positions.
} 


\section{FURTHER RESEARCH DIRECTIONS}

\subsection{Neg + copula incorporation}

A well-known fact about negation in Hungarian is that the $3^{\text {rd }}$ person present tense indicative copula is incorporated into the Neg particle, resulting in what is traditionally described as a negative existential verb (cf. É. Kiss 2015 a.o.): John not be.PAST.3sG home 'John was not at home.'
a. János nem volt otthon.
b. *János nem van otthon. John not be.3sg home intended: 'John is not at home.'
c. János nincs otthon. John not.be.3sg home 'John is not at home.'

Interestingly, such incorporation is optional in wh-exclamatives (47a, b) and impossible in Snegs $(47 c, d)$ :
a. (Hogy) mik nincsenek! that what.PL not.be.3PL
b. (Hogy) mik nem vannak! that what.PL not be.3PL
'What surprising things there are!'
c. Hát nem van egy testvérem!? ${ }^{21}$ well not be.3sg a brother.1sG
d. *Hát nincs(en) egy testvérem!? ${ }^{22}$ well not.be.3sG a brother.1sG '(It turns out) I have a brother! (unexpectedly)

Metalinguistic negation is also immune to incorporation:
a. A probléma nem van, hanem lesz. the problem not be.3sg but.rather be.3sG.FUT
b. *A probléma nincs(en), hanem lesz. the problem not.be.3sg but.rather be.3sG.FuT 'We do not have a problem, we will have a problem.'

\footnotetext{
${ }^{21}$ Source: https://www.wattpad.com/695759936-mivel-rajzolni-nem-tudok-h\%C3\%A1t-nem-van-egy-testv\%C3\%A9rem, downloaded: 11/11/2020.

${ }^{22}$ This sentence is of course grammatical as a rhetorical question with standard negation: 'Don't I have a brother?'
} 
Whereas in externally negated questions, incorporation is obligatory:
a. *János nem van már nyugdíjban? John not be.3sg already retirement.in
b. János nincs már nyugdíjban? John not.be.3sG already retirement.in
'Is it not our common knowledge that John is already retired?'

The theoretical literature, to our knowledge, has little to say about the specifics of the $\mathrm{Neg}+$ copula merger, other than that it requiers Neg and the $3^{\text {rd }}$ person copula to be adjacent. Whether this is linear adjacency at PF or adjacency in a deeper structural sense is left unspecified, probably because in standard negation, obligatory verb movement ensures that Neg and the verb are always adjacent both structurally and linearly (the only exception is when a focused element intervenes, duly blocking the incorporation). The varied (non)incorporation observations above suggest that one has to look beyond simple linear adjacency and consider the underlying structural configuration. However, a deeper analyis of this is beyond the scope of this paper.

\subsection{An innovative dialect}

For some speakers of Hungarian, nem in the standard negation position (NegP) can also be interpreted as expletive negation:
a. Hogy miket össze nem hordasz! (expletive negation, standard dialect) that what.PL.ACC PRT not gather.2sG
'What (nonsensical) things you are saying!'
b. Hogy miket nem hordasz össze! (expletive negation, innovative dialect) that what.PL.ACC not gather.2SG PRT
'What (nonsensical) things you are saying!'

As we have seen above, in many languages (e.g. Italian as reported by Delfitto, Melloni \& Vender (2019, 80-81)), standard negation and expletive with negation (with the exception of Snegs) occupy the same morphosyntactic position, and the interpretation of the negator as either standard or expletive is a function of context and pragmatics. Gugán (2020) argues that this was the case in Old Hungarian too. While Standard Modern Hungarian, the main focus of this paper, is similar to French (in that the old abandoned Neg position has been repurposed for expletive negation), the innovative dialect discussed in this subsection may represent a return to Italian-style shared syntactic position (Table 1):

Table 1 Standard and Expletive Negation: Diachrony

\begin{tabular}{|l|c|c|c|}
\hline & Old H. & Standard Mod. H. & Innovative Mod. H. \\
\hline head-adjoined to T & SN, EN & EN & \\
\hline NegP & & SN & SN, EN \\
\hline
\end{tabular}




\subsection{Idiomatic standard negation in the lower Neg-position}

There are three constructions in Modern Hungarian where standard negation is associated with the lowest Neg position: emphatic conditionals (51a), emphatic imperatives, directives and purposives and (51b) and emphatic assertions (51c):
a. Ha azonnal ki nem jössz, ...
if at.once PRT not come.2sG
'If you do not come out at once,...'
b. Meg ne próbáld!
PRT not try.2sG
'Don't you try it!'
c. Ki nem találod...
PRT not find.2sG
'You absolutely won't guess it!'

These are analyzed by É. Kiss (2010) and Ürögdi (2013) as “syntactic idioms", i.e., fossils from Old Hungarian; while Piñón (1991) argues that in such emphatic sentences, the negator is in fact in the standard negation position and the fact that it linearly follows the verbal particle is a consequence of the verbal particle itself having been focused for emphasis. Staying agnostic with regard to these models, we wish to add the descriptive characterization that all these constructions are modal in a general sense. The antecedent of a conditional and imperative/purposive/directive constructions are obviously modal, and the emphatic declaratives which exhibit this negation pattern are also modal: they either refer to the future as in (51c), or have a generic, habitual or volitional flavour. This suggests that in addition to emphasis, modality is also a crucial factor. Further investigation of this, however, is beyond the scope of this paper.

In conclusion, taking into consideration the innovative dialect and also idiomatic lower standard negation, the following scheme can be sketched (Table 2):

Table 2 Standard and Expletive Negation: Diachrony (Extended)

\begin{tabular}{|l|c|c|c|}
\hline & SDP & NegP & Neg $+\mathbf{T}$ \\
\hline Old Hungarian & $\mathrm{EN}_{\text {SNEG }}(?)$ & $\varnothing$ & $\mathrm{SN}, \mathrm{EN}_{\text {non-SNEG }}$ \\
\hline Standard Modern Hungarian & $\mathrm{EN}_{\text {SNEG }}$ & $\mathrm{SN}$ & $\mathrm{EN}_{\text {non-SNEG }}, \mathrm{SN}_{\text {idiomatic }}$ \\
\hline Innovative Modern Hungarian & $\mathrm{EN}_{\text {SNEG }}$ & SN, $\mathrm{EN}_{\text {non-SNEG }}$ & $\varnothing$ \\
\hline
\end{tabular}

\section{CONCLUSION}

This paper examined expletive negation in root clauses (surprise negation sentences and whexclamatives) in Hungarian. We argued that Hungarian has three distinct negation positions, each corresponding to a truth-reversal operation on a different level. When the negator nem 'no' is merged in the CP layer (in the head position of the Speaker Deixis Phrase), this yields surprise negation sentences, corresponding to negation at the level of presuppositions (expletive 
negation). The negator being merged as the head of NegP within the extended TP yields standard negation (at the propositional level). In wh-exclamatives, the negator is head-adjoined to $\mathrm{T}^{0}$, which results in negation at the level of implicatures (expletive negation).

These findings corroborate broadly Greco's (2019a) proposal (where different readings of the negator are associated with different structural positions) as opposed to an Espinal (2000)-style analysis (where standard and expletive negators are in the same position). In a more general sense, we argued that the data from Hungarian provide a nice fit with Delfitto, Meloni \& Vender's (2019) semantic-pragmatic proposal, inasmuch as the domain of operation (implication, assertion, presupposition) is clearly mapped to the syntactic position of the negator.

In addition to pointing out this mapping between syntactic position and semantic-pragmatic interpretation, we also argued that the data from Hungarian present a strong case against a raising analysis of expletive negation. Finally, we sketched some promising topics for further research, including the (lack) of Neg+copula incorporation in certain cases of expletive negation.

\section{ACKNOWLEDGEMENTS}

The authors' names appear in alphabetical order. We wish to thank the participants of SinFonIJA 13 and our colleagues in the 'Implications of endangered Uralic languages for syntactic theory and the history of Hungarian' project, as well as two anonymous reviewers and the editors for helpful comments and advice. The research reported here was supported by a Postdoctoral Grant of the Hungarian Academy of Sciences (PPD 031/2017), Project Grant 129921 of the National Research, Development and Innovation Office of Hungary and Grant TKP2020-NKA-11 of the Ministry for Innovation and Technology of Hungary.

\section{REFERENCES}

Abels, Klaus. 2005. "Expletive negation” in Russian: A conspiracy theory. Journal of Slavic Linguistics 13. 5-74.

Bartos, Huba. 2020. Mi mindent tudunk a mi minden-típusú kérdésekröl? [What all do we know about the mi minden 'what all'-type questions?]. In É. Dékány, T. Halm and B. Surányi (eds.) Általános Nyelvészeti Tanulmányok XXXII. Budapest: Akadémiai Kiadó. 249-264.

Brown, Sue and Steven Franks. 1995. Asymmetries in the scope of Russian negation. Journal of Slavic Linguistics 3. 239-287.

Delfitto, Denis, Chiara Melloni and Maria Vender. 2019. The (en)rich(ed) meaning of expletive negation. Evolutionary Linguistic Theory 1. 57-89.

É. Kiss, Katalin. 2008. Free word order, (non)configurationality, and phases. Linguistic Inquiry 39. 441-475.

É. Kiss, Katalin. 2009a. Negative quantifiers in Hungarian. In M. den Dikken and R. Vago (eds.) Approaches to Hungarian 11. Amsterdam: John Benjamins. 65-94.

É. Kiss, Katalin. 2009b. Syntactic, semantic, and prosodic factors determining the position of adverbial adjuncts. In K. É. Kiss (ed.) Adverbs and adverbial adjuncts at the interfaces. Berlin: Walter de Gruyter. $21-38$. 
É. Kiss, Katalin. 2010. An adjunction analysis of quantifiers and adverbials in the Hungarian sentence. Lingua 120. 506-526.

É. Kiss, Katalin. 2014. The evolution of functional left peripheries in the Hungarian sentence. In K. É. Kiss (ed.) The evolution of functional left peripheries in Hungarian syntax. Oxford: Oxford University Press. 9-55.

É. Kiss, Katalin. 2015. Negation in Hungarian. In M. Matti, A. Tamm and B. Wagner-Nagy (eds.) Negation in Uralic languages. Amsterdam: John Benjamins. 219-238.

Egedi, Barbara. 2009. Adverbial (dis)ambiguities: Syntactic and prosodic features of ambiguous predicational adverbs. In K. É. Kiss (ed.) Adverbs and adverbial adjuncts at the interfaces. Berlin: Mouton de Gruyter. 103-132.

Elliott, Dale E. 1974. Toward a grammar of exclamations. Foundations of Language 11. 231-246.

Ernst, Thomas 2002. The Syntax of Adjuncts. Cambridge University Press, Cambridge.

Espinal, Maria Teresa. 1997. Non-negative negation and wh-exclamatives. In D. Forget, P. Hirschbühler, F. Martineau and M. L. Rivero (eds.) Negation and polarity. Syntax and semantics. Amsterdam: John Benjamins. 75-93.

Espinal, Maria Teresa. 2000. Expletive negation, negative concord and feature checking. Catalan Working Papers in Linguistics 8. 47-69.

Gärtner, Hans Martin and Beáta Gyuris. 2012. Pragmatic markers in Hungarian: Some introductory remarks. Acta Linguistica Hungarica 59. 387-426.

Greco, Matteo. 2018. A twofold classification of expletive negation. In R. Stockwell, M. O’Leary, Zh. Xu and Z.L. Zhou (eds.) Proceedings of the 36th West Coast Conference on Formal Linguistics (WCCFL). Somerville, MA: Cascadilla Proceedings Project. 165-175.

Greco, Matteo. 2019a. On the syntax of surprise negation sentences: A case study on expletive negation. Natural Language \& Linguistic Theory 38. 775-825.

Greco Matteo. 2019b. Is expletive negation a unitary phenomenon? Lingue e Linguaggio 1. 25-58.

Grimshaw, Jane. 1979. Complement selection and the lexicon. Linguistic Inquiry 10. 279-326.

Gugán, Katalin. 2017. A magyar tagadó mondatok szórendje és a konstansráta-hipotézis [The word order of negation in Hungarian and the constant rate hypothesis]. In K. É. Kiss, A. Hegedüs and L. Pintér (eds.) Nyelvelmélet és diakrónia 3 [Linguistic theory and diachrony 3]. Budapest \& Piliscsaba: Elméleti Nyelvészeti Tanszék - Magyar Nyelvészeti Tanszék, BTK, PPKE. 91-110.

Gugán Katalin. 2018. Hagyomány és innováció középmagyar kori bibliafordítások mondattanában: a tagadás változatai [Tradition and innovation in the syntax of Middle Hungarian Bible translations: Variations of negation]. In K. É. Kiss, A. Hegedüs and L. Pintér (eds.) Nyelvelmélet és dialektológia 4: A Károli-biblia nyelve [Linguistic theory and dialectology 4: The language of the Károli Bible]. Budapest \& Piliscsaba: Elméleti Nyelvészeti Tanszék - Magyar Nyelvészeti Tanszék, BTK, PPKE. 57-75.

Gugán, Katalin. 2020. Expletive negation in Middle Hungarian. Talk given at the 13th Conference on Syntax, Phonology, and Language Analysis (SinFonIJA 13). Research Institute for Linguistics, Budapest September 24-26, 2020.

Gyuris, Beáta. 2016. A magyar nyelv tagadószós eldöntendő kérdő mondatainak jelentéséhez [On the semantics of yes-no questions with negation in Hungarian]. Jelentés és Nyelvhasználat 3. 169-190.

Haegeman, Liliane. 2006. Conditionals, factives, and the left periphery. Lingua 116. 1651-1669.

Halm, Tamás. 2021. Radically truncated clauses in Hungarian \& beyond: Evidence for the fine structure of the minimal VP. Syntax 24. 376-416.

Jespersen, Otto. 1917. Negation in English and other languages. Copenhagen: A. F. Høst.

Kálmán, László. 2001. Magyar leíró nyelvtan: Mondattan [A descriptive grammar of Hungarian: Syntax]. Budapest: Tinta Könyvkiadó. 
Kálmán, László. 2016. Hogy miket (nem) mondunk [What all we are (not) saying?!] Blogpost in Nyelv és Tudomány. https://m.nyest.hu/hirek/hogy-miket-nem-mondunk.

Link, Godehard. 1983. The logical analysis of plurals and mass terms: A lattice-theoretical approach. In R. Bäuerle, C. Schwarze and A. von Stechow (eds.) Meaning, use and interpretation of language. Berlin: Walter de Gruyter. 302-323.

Lipták, Anikó. 2006. Word order in Hungarian exclamatives. Acta Linguistica Hungarica 53. 343-391. MacDonald, Jonathan A. and Barbara Ürögdi. 2011. Against stativizing negation, expletive negation and NPI-until. Acta Linguistica Hungarica 58. 203-220.

Makri, Maria-Margarita. 2013. Expletive negation beyond Romance: Clausal complementation and epistemic modality. MA thesis. University of York, York.

Michaelis, Laura A. and Knud Lambrecht. 1996. The exclamative sentence type in English. In A. Goldberg (ed.) Conceptual structure, discourse and language. CSLI Publications: Stanford, CA. 375-389.

Nouwen, Rick and Anna Chernilovskaya. 2015. Two types of exclamatives. Linguistic Variation 15. 201-224.

Olsvay, Csaba. 2000. A syntactic analysis of negative universal quantifiers in Hungarian. MA thesis. Eötvös Loránd University, Budapest.

Piñón, Christopher. 1991. Presupposition and the syntax of negation in Hungarian. In L. N. Dobrin, L. Nichols and R. M. Rodriguez (eds.) Papers from the 27th Regional Meeting of the Chicago Linguistic Society, Part two: The parasession on negation. Chicago, IL: Chicago Linguistic Society. 246-262.

Portner, Paul and Raffaella Zanuttini. 2000. The force of negation in wh exclamatives and interrogatives. In

L. R. Horn and Y. Kato (eds.) Negation and polarity: Syntactic and semantic perspectives. Oxford: Oxford University Press. 193-231.

Puskás, Genovéva. 2000. Word order in Hungarian: The syntax of Ā-positions. Amsterdam: John Benjamins.

Rákosi, György. 2008. Some remarks on Hungarian ethical datives. In J. Andor (ed.) When grammar minds language and literature: Festschrift for Prof. Béla Korponay on the occasion of his 80th birthday. Institute of English and American Studies, University of Debrecen. 413-422.

Simonyi, Zsigmond. 1883. A magyar kötőszók, egyúttal az összetett mondat elmélete [A theory of conjunction and complex sentences in Hungarian]. Budapest: Magyar Tudományos Akadémia.

Simonyi, Zsigmond. 1902. A magyar szórend VI.: A kirekesztő (tagadó) szórend [The word order of Hungarian 6: The word order of exclusion (negation)]. Magyar Nyelvőr 31. 359-379.

Stutterheim, Christiane von and Wolfgand Klein. 1989. Referential movement in descriptive and narrative discourse. Linguistic Variations 54. 39-76.

Surányi, Balázs. 2002. Multiple operator movements in Hungarian. PhD dissertation. University of Utrecht, Utrecht.

Tenny, Carol. 2000. Core events and adverbial modification. In C. Tenny and J. Pustejovsky (eds.) Events as grammatical objects: The converging perspectives of lexical semantics and syntax. Stanford, CA: CSLI Publications. 285-334.

Tóth, Ildikó. 1999. Negative polarity item licensing in Hungarian. Acta Linguistica Hungarica, 46(1-2), 119-142.

Turi, Gergö. 2015. Nem mintha egyszerü lenne: A nem mintha szerkezet elemzése [Not that it is easy: An analysis of the nem mintha 'not that' construction]. In Zs. Gécseg (ed.) Proceedings of the LINGDOK 14 Conference. Szeged: University of Szeged Doctoral School of Linguistics. 221-238.

Ürögdi, Barbara. 2013. Adverbial clauses with -ig and the "until-puzzle". Acta Linguistica Hungarica 60. 303-363.

Varga, László. 2002. Intonation and stress: Evidence from Hungarian. Basingstoke \& New York, NY: Palgrave Macmillan. 
van der Wouden, Ton. 1994. Polarity and 'illogical negation'. In M. Kanazawa and Ch. J. Piñón (eds.) Dynamics, polarity, and quantification. Stanford: CSLI. 17-45.

van der Wouden, Ton. 1997. Negative contexts: Collocation, polarity and multiple negation (Routledge Studies in Germanic Linguistics). London: Routledge.

Yoon, Suwon. 2011. 'Not' in the mood: The syntax, semantics, and pragmatics of evaluative negation. $\mathrm{PhD}$ dissertation. University of Chicago, IL.

Zanuttini, Raffaella and Paul Portner. 2000. The characterization of exclamative clauses in Paduan. Language 76. 123-132.

Zanuttini, Raffaella and Paul Portner 2003. Exclamative clauses: At the syntax-semantics interface. Language (2003): 39-81.

Zeijlstra, Hedde. 2004. Sentential negation and negative concord. PhD dissertation. University of Amsterdam, Amsterdam.

Zovko Dinković, Irena and Gašper Ilc. 2017. Pleonastic negation from a cross-linguistic perspective. Jezikoslovlje 18. 159-180.

Open Access. This is an open-access article distributed under the terms of the Creative Commons Attribution 4.0 International License (https://creativecommons.org/licenses/by/4.0/), which permits unrestricted use, distribution, and reproduction in any medium, provided the original author and source are credited, a link to the CC License is provided, and changes - if any - are indicated. (SID_1) 